Richard Butterwick-Pawlikowski

\title{
'In the Greatest Wildness of my Youth': Sir Charles Hanbury Williams and Mid-Eighteenth-Century Libertinism
}

This article has been accepted for publication in the Journal of Eighteenth-Century Studies. It is placed in the UCL repository in order to meet REF requirements.

CRichard Butterwick-Pawlikowski 2016. Not for citation or quotation without permission. 


\title{
'In the Greatest Wildness of my Youth': Sir Charles Hanbury Williams and Mid-Eighteenth-Century Libertinism*"
}

\section{Richard Butterwick-Pawlikowski}

\begin{abstract}
Much has been written about discourses concerning male sexual behaviour in the eighteenth century; given the nature of the surviving sources, it is harder to research actual sexual behaviour. Sir Charles Hanbury Williams (1708-1759) was a celebrated poet, wit and diplomat in his own lifetime, but is now largely forgotten. The copious surviving manuscripts of his correspondence and verses provide rich and explicit material for an examination of mid-eighteenth-century libertinism from two perspectives - that of its ribald practitioners, and that of an ex-libertine father and mentor - within the context of scholarly debates on eighteenth-century politeness and masculinities.
\end{abstract}

\section{Keywords}

Sir Charles Hanbury Williams - libertinism - sexuality - politeness - masculinity paternity

In his own lifetime (1708-1759), and for a short time afterwards, Sir Charles Hanbury Williams was celebrated, first as 'a poet of great genius and wit', and then as a diplomat, whose despatches were 'much admired' as models of English prose. ${ }^{1} \mathrm{He}$ is now almost completely forgotten in the history of English literature, and is but a minor figure in British diplomatic history. He is probably best known through biographies of Catherine the Great.

\footnotetext{
* I wish to thank the Lewis Walpole Library for the award of a fellowship in 2001, the Interdisciplinary Seminar in Eighteenth-Century Studies at the University of Nottingham and the Honourable Society of Cymmrodorion for invitations to present my research, the anonymous readers for their valuable comments, and Professor Lynda Pratt and Dr Ian Packer for all their advice and support.

1 'Walpole's Account of Sir Charles Hanbury Williams', in Horace Walpole's Correspondence with George Selwyn, Lord Lincoln, Charles Hanbury Williams, Henry Fox, Edward Edgcumbe, ed. W. S. Lewis and Robert A. Smith, The Yale Edition of Horace Walpole's Correspondence, vol. 30, New Haven, CT: Yale University Press, 1961, appendix 3, pp. 311-23, quoted at 313, 320. The Yale Edition, ed. W. S. Lewis et al., 48 vols, New Haven, CT: Yale University Press, 1938-83, is fully available online (http://images.library.yale.edu/hwcorrespondence/, accessed 21 August 2015).
} 
As Ambassador to Russia in 1755-57, he befriended the Grand Duchess Catherine, a few years before the coup of 1762 in which she seized the Russian imperial throne from her husband, Peter III. He facilitated her second love affair - with Stanisław Poniatowski, whom Catherine later made King of Poland. ${ }^{2}$ Williams's influence on Poniatowski was still more profound. ${ }^{3}$ Yet the life, letters and loves of Sir Charles reward study in their own right. Played out on stages from Monmouthshire to London to Hanover to Vienna to Berlin to Dresden to Warsaw to St Petersburg, they cast light on the histories of diplomacy, politics, society, literature, manners, sex, friendship, marriage and fatherhood in the middle decades of the eighteenth century. They are especially illuminating on libertinism, because they view the phenomenon from the perspectives both of its riotous practitioners, and from the retrospective viewpoint of a former, partly repentant libertine. This shift in perspective was enshrined in the life-story of Sir Charles Hanbury Williams, which, given his almost complete absence from works on libertinism, ${ }^{4}$ is worth recalling here.

In 1708 few would have expected the newborn Charles Hanbury, fourth son of Major John Hanbury of Pontypool, to achieve either distinction or notoriety in so many spheres of life. ${ }^{5}$ True, the Hanburys were among the wealthiest gentry of South Wales,

\footnotetext{
${ }^{2}$ See, inter alia, Isabel de Madariaga, Russia in the Age of Catherine the Great, New Haven, CT: Yale University Press, 1981, pp. 11-14; John T. Alexander, Catherine the Great: Life and Legend, New York: Oxford University Press, 1989, pp. 47-57; Simon Dixon, Catherine the Great, London: Profile, 2009, pp. 18, 93-105, 185, 332-33.

${ }^{3}$ Juljan Nieć, Mtodość ostatniego elekta. St. A. Poniatowski 1732-1764, Kraków: Gebethner i Wolff, 1935, passim; Jean Fabre, Stanislas-Auguste Poniatowski et l'Europe des lumières. Étude de cosmopolitisme, Paris: Institut d'Études Slaves, 1952, pp. 170-74; Adam Zamoyski, The Last King of Poland, London: Jonathan Cape, 1992, pp. 29-72; Richard Butterwick, Poland's Last King and English Culture: Stanistaw August Poniatowski 1732-1798, Oxford: Clarendon Press, 1998, pp. 81, 86-121; Krystyna Zienkowska, Stanisław August Poniatowski, Wrocław: Ossolineum, 1998, pp. 52, 64, 73-97, 102.

${ }^{4}$ Faramerz Dabhoiwala, The Origins of Sex: A History of the First Sexual Revolution, London: Allen Lane, 2012, quotes two poems 'by the libertine poet and politician Sir Charles Hanbury Williams' at pp. 130, 132-33. Otherwise, it suffices to check the indexes of the works listed in footnotes 23, 24, 25 and 27 below.

${ }^{5}$ The following biographical outline is based, unless indicated otherwise, on Mary Margaret Stewart, 'Williams, Sir Charles Hanbury (1708-1759)', Oxford Dictionary of National Biography, Oxford: Oxford University Press, 2004, online edn 2008 (henceforth $O D N B$; http://www.oxforddnb.com/view/article/29488, accessed 21 August 2015), and [Giles Stephen Holland Fox-Strangways,] the [Sixth] Earl of Ilchester, and Mrs [Elizabeth] Langford-Brooke, The Life of Sir Charles Hanbury Williams, Poet, Wit and Diplomatist, London: T. Butterworth, 1929.
} 
having moved there from Worcestershire and made their fortune in iron and tin. John Hanbury was a borough MP - for Gloucester - between 1701 and 1715, and a county MP for Monmouthshire, between 1720 and $1734 .{ }^{6}$ In 1720 he inherited $£ 70,000$ from his friend Charles Williams, who had made his initial money trading in Smyrna following his flight from Wales after killing his cousin in a duel. Hanbury's efforts enabled Williams to return home and enlarge his fortune. The bulk of Williams's legacy was intended for his godson John's fourth son, Charles - who on coming of age in 1729 re-styled himself Charles Hanbury Williams. ${ }^{7}$ He received the substantial estate of Coldbrook Park, south of Abergavenny, bought for him by his father out of the Williams legacy. In 1732, Charles Hanbury Williams married Frances, second daughter and co-heiress of Thomas, first Earl Coningsby, ${ }^{8}$ and granddaughter and co-heiress of Richard, first Earl of Ranelagh. ${ }^{9}$ They had two daughters, Fanny and Charlotte. Two years later, he was elected to Parliament, succeeding his father as MP for Monmouthshire, which he represented until he stood aside for his elder brother, Capel Hanbury, in 1747. Although no great parliamentarian, he served Sir Robert Walpole and Henry Pelham by lampooning their opponents. He was rewarded in 1744 when George II created him a Knight of the Bath. In sum, Williams enjoyed the blessings of good fortune in his youth, and could have led a fulfilled and comfortable life. Instead, he died in misery and madness at the age of fifty-one.

The chief reason may be traced to the company Williams kept in London: a libertine circle notorious for promiscuous and omnivorous sexual liaisons. This lifestyle inspired much of his poetry, but also caused the severe syphilis that destroyed his marriage and, ultimately, his mind. His dearest friend, Thomas Winnington, died in 1746. Following an embarrassing, although not incriminating inquiry into his handling of the monies entrusted to him as Paymaster of the Marines, and having made too many enemies with his versed barbs, Williams sought a diplomatic posting abroad.

\footnotetext{
${ }^{6}$ Philip Riden 'Hanbury, John (1664?-1734)', ODNB (http://www.oxforddnb/view/article/12181, accessed 21 August 2015).

${ }^{7}$ Robert Thomas Jenkins, 'Williams, Charles (1633-1720)', Dictionary of Welsh Biography (http://yba.1lgc.org.uk/en/s-WILL-CHA-1633.html, accessed 21 August 2015).

${ }^{8}$ A. E. Stokes, 'Coningsby, Thomas, First Earl of Coningsby (1657-1729)', ODNB (http://www.oxforddnb.com/view/article/6076, accessed 21 August 2015).

${ }^{9}$ C. I. McGrath, 'Jones, Richard, Earl of Ranelagh (1641-1712)', ODNB (http://www.oxforddnb.com/view/article/15072, accessed 21 August 2015).
} 
Sir Charles hoped for the warmer climes of Turin. Instead, he was posted in the rank of minister to Dresden and Warsaw. The Elector of Saxony was also King Augustus III of Poland. Williams usually resided with the court in Dresden, or one of the other Saxon royal residences, but accompanied the King on biennial trips to Warsaw for sessions of the Polish parliament, or sejm. Sir Charles's principal task was to win Saxon support for British and Hanoverian interests in the Holy Roman Empire. Saxony was to be brought into a closer relationship with Great Britain's traditional ally, the Habsburg Monarchy, and with Austria's ally, Russia, while countering French and Prussian influence in Saxony and Poland. During his tenure of the Saxon-Polish mission Williams was also sent on extraordinary missions to the courts of Berlin (in 1750-51) and Vienna (1751 and 1753), none of which were a clear success. He took extended leave to return home in 1749-50 and $1753-54 .^{10}$

Once removed from London, Williams settled into an avuncular middle age. $\mathrm{He}$ became an affectionate and conscientious father, although mostly removed from his daughters, and a father-figure to several young men. These included his own son-in-law, William Capel, fourth Earl of Essex, and Harry Digby, nephew to another of Sir Charles's close friends, Henry Fox. Most intensively, he became a 'second father' to Stanisław Poniatowski. Their correspondence attests a relationship that was paternal and filial, but not pederastic. ${ }^{11}$ Williams met Poniatowski in Berlin in 1750, and subsequently spent time with him in Poland-Lithuania, Saxony, Austria, Hanover, and the Netherlands. When Sir Charles was nominated Ambassador to Russia in 1755, Poniatowski went with him as his secretary.

The Russian Empire was then ruled by the beautiful, capricious, and hedonistic Elizabeth, daughter of Peter the Great. Sir Charles began well, concluding negotiations for a Russo-British treaty. Russia promised to attack Prussia, if Prussia attacked Hanover. Unfortunately for Williams, the ground was cut from under his feet, when the Duke of Newcastle's ministry concluded the so-called Convention of Westminster with Prussia. Elizabeth understandably took umbrage, shattering the Russo-British rapprochement, and the Austrian court concluded a treaty with France. Frederick the Great then invaded

\footnotetext{
${ }^{10}$ See D. B. Horn, Sir Charles Hanbury Williams and European Diplomacy 1746-1758, London: Harrap, 1930.

${ }^{11}$ Cf. Butterwick, Poland's Last King, p. 86-87. Although I have since come across a great deal of evidence regarding Williams's sexuality, none of it indicates a physical sexual relationship with Poniatowski.
} 
Saxony, provoking the Seven Years' War and completing the Diplomatic Revolution. ${ }^{12}$ Williams's work lay in ruins. London had usually given him poor hands to play, and when, in Russia, he succeeded, Newcastle snatched the cards away.

During these years abroad, Williams experienced bouts of depression and migraines, attributable to the long-term effects of syphilis. Low in spirits and weak in body after the failure of his mission to Russia, he experienced a terrible journey home to Britain in 1757-58, during which he suffered a mental breakdown. He had periods of relative lucidity after that, but never fully recovered. He initially resided at Coldbrook, but was officially confined as a lunatic, and kept in a house in London early in 1759. He died, possibly by his own hand, on 2 November of that year. Eight days later, he was interred in Westminster Abbey.

Sir Charles Hanbury Williams left a wealth of sources to record his life and works. Nearly a hundred volumes of his papers are preserved in the Lewis Walpole Library at Farmington, Connecticut. They include the manuscripts of his poems, some political correspondence, and a vast quantity of letters from and to family and friends. These include many uninhibited letters from his fellow-libertines in the early and mid-1740s, when he wrote most of his verses. From 1747 onwards there is a voluminous correspondence with his daughters. Williams's letters to Henry Fox and the Duke of Newcastle are in the British Library, his letters to the Poniatowskis and Czartoryskis are in the Central Archives of Historical Records (AGAD) in Warsaw, while his official despatches are in the National Archives at Kew. Twenty-seven boxes in Newport Public Library contain many of Williams's diplomatic papers, as well as documents relating to the Hanbury family and their estates. The published sources include the correspondence between Sir Charles and Catherine, some of the letters from Poniatowski, the latter's memoirs, and passing mentions by the diarists and correspondents of the age. ${ }^{13}$

\footnotetext{
${ }^{12}$ D. B. Horn, 'The Diplomatic Revolution', in The New Cambridge Modern History, vol. 7, The Old Regime 1713-63, ed. J. O. Lindsay, Cambridge: Cambridge University Press, 1966, pp. 440-64, is a lucid guide to events. See also Herbert Kaplan, Russia and the Outbreak of the Seven Years' War, Berkeley and Los Angeles, CA: University of California Press, 1968.

${ }^{13}$ Correspondance de Catherine Alexéiewna, Grande-Duchesse de Russie, et de Sir Charles H. Williams, Ambassadeur d'Angleterre, 1756 et 1757, ed. Serge Goryaïnow, Moscow: Société Impériale d'Histoire et d'Antiquités Russes, 1909; Correspondence of Catherine the Great, when Grand Duchess, with Sir Charles Hanbury Williams, and Letters from Count Poniatowski, trans. and ed. [Giles Stephen Holland FoxStrangways,] the [Sixth] Earl of Ilchester, and Mrs [Elizabeth] Langford-Brooke, London: T. Butterworth,
} 
No previous work on Sir Charles Hanbury Williams has made use of all these sources. Until quite recently, some of them would have been unpublishable. It was on grounds of indecency, rather than 'dullness' that Robert Southey, the future Poet Laureate, turned down the chance to edit his poetical and prose works in 1802:

A bookseller offered me fifty pounds worth of books last week to edit the works of Sir Charles Hanbury Williams. lead us not into temptation! - I looked over the papers - I liked his wit - I did not like his dullness - but fifty pounds of books would have gilt that pill - but my gentleman was not quite so decent as he should be $-\&$ so I lost my books. my name was not required for the work. ${ }^{14}$

When most of the poems, pruned of some of the worst obscenities, were injudiciously published in three volumes in 1822 , they ruined the remnants of Williams's reputation. ${ }^{15}$

The year 1929 saw the publication of a biography of Williams by Giles, sixth Earl of Ilchester, and Mrs Elizabeth Langford-Brooke. It was based on the papers that subsequently found their way to Farmington, those then in Holland House, and those which were already in the public domain in Great Britain. The authors sought to rehabilitate Williams, and left out the coarser material. ${ }^{16}$ A year later, however, Williams's diplomacy was excoriated by David Bayne Horn. ${ }^{17}$ Seven decades afterwards, Paweł Hanczewski offered a more positive assessment than Horn of British policy towards Central and Eastern Europe between the War of the Austrian Succession and the Seven

1928; Stanislas Auguste, Mémoires, ed. Anna Grześkowiak-Krwawicz and Dominique Triaire, Paris: Institut d'Études Slaves, 2012.

${ }^{14}$ Robert Southey to Charles Danvers, 23 March 1802, no. 664, The Collected Letters of Robert Southey, part 2, ed. Ian Packer and Lynda Pratt, Romantic Circles, University of Maryland (http://www.rc.umd.edu/editions/southey_letters/Part_Two/HTML/letterEEd.26.664.html\#, accessed 21 August 2015)

${ }^{15}$ The Works of the Right Honorable Sir Chas. Hanbury Williams, 3 vols, London: Edward Jefferies and Son, 1822.

${ }^{16}$ Ilchester and Langford-Brooke, The Life of Sir Charles Hanbury Williams.

${ }^{17}$ Horn, Sir Charles Hanbury Williams. An otherwise impressed reviewer, L. G. Wickham Legg, questioned Horn's unforgiving verdict: English Historical Review, vol. 46, no. 182 (1931), pp. 302-04. 
Years' War, but gave no clear verdict on Williams's performance as a diplomat. ${ }^{18}$ Tone Urstad's doctoral thesis of 1987 established, as far as possible, what Williams wrote, and what he did not write. ${ }^{19}$ The entry in the Oxford Dictionary of National Biography, by Mary Margaret Stewart, is especially authoritative on Williams's syphilis. ${ }^{20}$ Williams and his works are cited as evidence for the case made by Hannah Smith and Stephen Taylor that John, Lord Hervey, belonged to 'a group of friends among whom coarse ribaldry, embracing both homoerotic and heterosexual desire, was a key dynamic. ${ }^{21}$ Finally, Faramerz Dabhoiwiala quotes from two of Williams's poems to exemplify his thesis of the increasing sexual freedom of the long eighteenth century. ${ }^{22}$

Pending a full-length study of the richly documented life and works of Sir Charles Hanbury Williams, the current article views the theme of libertinism through the lenses of Williams's correspondence and verses. Libertinism overlaps with the fields of politeness and masculinity. Long-term shifts from early modern courtesy through eighteenth-century politeness and sensibility to nineteenth-century etiquette have been traced and discussed in gendered, family, and social and political perspectives. Despite differences of emphasis (between physiology and the emotions, for example) and the unspent ideological controversy between the adherents of 'constructionist' and 'essentialist' interpretations of sexuality, ${ }^{23}$ several important points have emerged.

${ }^{18}$ Paweł Hanczewski, Dyplomacja brytyjska w Europie środkowo-wschodniej w latach 1748-1756. Misje w Berlinie, Dreźnie, Wiedniu i Petersburgu, Toruń: Adam Marszałek, 2000.

${ }^{19}$ Tone Dagny Sundt Urstad, 'The Works of Sir Charles Hanbury Williams', unpublished Ph.D dissertation, University of Cambridge, 1987. See also eadem, Sir Robert Walpole's Poets: The Use of Literature as Pro-Government Propaganda 1721-1742, Newark, NJ: University of Delaware Press, 1999.

${ }^{20}$ Stewart, 'Williams, Sir Charles Hanbury'; eadem, “"And Blights with Plagues the Marriage Hearse”: Syphilis and Wives', in Linda E. Merians (ed.), The Secret Malady: Venereal Disease in Eighteenth-Century Britain and France, Lexington, KY: University of Kentucky Press, 1996, pp. 103-13.

${ }^{21}$ Hannah Smith and Stephen Taylor, 'Hephaestion and Alexander: Lord Hervey, Frederick Prince of Wales and the Royal Favourite in England in the 1730s', English Historical Review, 124, no. 507 (2009), pp. 283-312, at 297-99.

${ }^{22}$ See note 4 above.

${ }^{23}$ See Caroline Gonda and Chris Mounsey, 'Queer People: An Introduction', in Chris Mounsey and Caroline Gonda (eds), Queer People: Negotiations and Expressions of Homosexuality, 1700-1800, Danvers, MA: Rosemount Publishing, 2007, pp. 9-25. 
First, the idiom of politeness could be applied in diverse ways. Second, persons from many walks of life claimed a degree of 'politeness' - which was often acknowledged by others. Third, the association of politeness with mixed-sex company gave rise to anxieties that 'effeminacy' was sapping the manly virtues of the nation. Fourth, and most importantly here, the eighteenth century's generally dominant discourses of male politeness both reacted to older patterns of impolite behaviour and in turn provoked rebellions against polite norms. ${ }^{24}$ From this follows a final point, namely that aristocratic libertines conducted themselves impolitely, but in underlining their own exceptional status they did not undermine the general standards of a socially much broader polite society: in some respects, the 'rakes' even reinforced the norms they transgressed. ${ }^{25}$ It remains the case, however, that the discourse and representation of male behaviour have - at least until

\footnotetext{
${ }^{24}$ Some notable landmarks are Michael Curtin, 'A Question of Manners: Status and Gender in Etiquette and Courtesy', Journal of Modern History, 57 (1985), 3, pp. 395-423; Paul Langford, A Polite and Commercial People: England 1727-1783, Oxford: Oxford University Press, 1989; Lawrence E. Klein, 'Liberty, Manners and Politeness in Early Eighteenth-Century England', Historical Journal, 32 (1989), 3, pp. 583-605; G. J. Barker-Benfield, The Culture of Sensibility: Sex and Society in Eighteenth-Century Britain, Chicago, IL: University of Chicago Press, 1992; Rictor Norton, Mother Clap's Molly House: The Gay Subculture in England, 1700-1830 [1992], revised edn, Romford: Chalford Press, 2006; Lynn Hunt (ed.), The Invention of Pornography: Obscenity and the Origins of Modernity, Cambridge, MA: MIT Press, 1993; Amanda Vickery, The Gentleman's Daughter: Women's Lives in Georgian England, New Haven, CT: Yale University Press, 1998; Randolph Trumbach, Sex and the Gender Revolution, vol. 1, Heterosexuality and the Third Gender in Enlightenment London, Chicago, IL: University of Chicago Press, 1998; Tim Hitchcock and Michèle Cohen (eds), English Masculinities, 1660-1800, London: Routledge, 1999; George E. Haggerty, Men in Love: Masculinity and Sexuality in the Eighteenth Century, New York: Columbia University Press, 1999; Philip Carter, Men and the Emergence of Polite Society, Britain 1660-1800, Harlow: Longman, 2001; Paul Langford, 'The Uses of Eighteenth-Century Politeness', Transactions of the Royal Historical Society, 6th series, 12 (2002), pp. 311-31; Karen Harvey, Reading Sex in the Eighteenth Century: Bodies and Gender in English Erotic Culture, Cambridge: Cambridge University Press, 2004; eadem, 'The History of Masculinity, circa 1650-1800', Journal of British Studies, 44 (2005), 2, pp. 296-311; Matthew McCormack, The Independent Man: Citizenship and Gender Politics in Georgian England, Manchester: Manchester University Press, 2005; Vic Gatrell, City of Laughter: Sex and Satire in Eighteenth-Century London, London: Atlantic Books, 2006; Katherine O’Donnell and Michael O'Rourke (eds), Love, Sex, Intimacy and Friendship between Men, 1550-1800, Basingstoke: Palgrave Macmillan, 2007; Karen Harvey, The Little Republic: Masculinity and Domestic Authority in Eighteenth-Century Britain, Oxford: Oxford University Press, 2012.

${ }^{25}$ Jason M. Kelly, The Society of Dilettanti: Archaeology and Identity in the British Enlightenment, New Haven, CT: Yale University Press, 2009, especially at pp. 58-59.
} 
very recently - attracted more attention than male behaviour itself. This is not surprising, given that most of the surviving sources lend themselves more easily to the former than the latter. $^{26}$ The evidence that follows may help to bridge that gap.

$$
* * *
$$

The words 'libertinage' and 'libertinism' connote both sexual freedom (or licentiousness, even to the extent of publicly avowed rapacious lechery among Restoration libertines) and a proclivity to mock religion. There is no consensus, however, on the proportions and the relationships between the two elements. To take a somewhat unusual case, the third Earl of Shaftesbury rebuked coarse and incontinent sexual behaviour while employing a language of philosophical libertinism that was tinged with homoerotic desire. It seems reasonable to conclude that the weakening of religious restraints facilitated promiscuous and even predatory behaviour, but that the fashionability of 'rakish' (mis)conduct also provided an incentive for 'irreligion'. 27

We find both of these themes in Williams's papers. In an undated note to her estranged husband, Lady Frances Hanbury Williams vented her anger at having to let Fanny and Charlotte stay with him: 'Since I find you are as determin'd your children shall have as little Religion as your self I have sent them, both, so that you may employ them as you think fit'. ${ }^{28}$ Later in life, however, Sir Charles commended to his future son-in-law

\footnotetext{
${ }^{26}$ Lawrence E. Klein, 'Politeness and the Interpretation of the British Eighteenth Century', Historical Journal, 45 (2002), 4, pp. 869-98, at p. 878. Dabhoiwala, The Origins of Sex, covers transformations of both 'the perception, and the experience, of sex' (p. 4 and passim), but says more on the former.

${ }^{27}$ For a wide-ranging discussion, see Jean-Christophe Abramovici, 'Libertinism', in Michel Delon (ed.), Encyclopedia of the Enlightenment, Abingdon: Routledge, 2013, pp. 772-76. On Shaftesbury: Brian Cowan, 'Reasonable Ecstasies: Shaftesbury and the Languages of Libertinism', Journal of British Studies, 37 (1998), 2, pp. 111-38. See also Peter Cryle and Lisa O’Connell, 'Sex, Liberty and Licence' in Cryle and O’Connell (eds), Libertine Enlightenment: Sex, Liberty and Licence in the Eighteenth Century, Basingstoke: Palgrave Macmillan, 2003, pp. 1-14. Particularly relevant here - although its thesis is contested - is Trumbach, Sex and the Gender Revolution, vol. 1, pp. 69-111. Cf. Dabhoiwala, The Origins of Sex, pp. 98- 110, 149-53 (for the 'rapacious' libertine), and the dispute between Jason M. Kelly and Shearer West referenced in n. 33 below. Stanisław August Poniatowski for one believed that the tendency towards 'philosophie' among French ladies derived from their sexual 'libertinage'. Butterwick, Poland's Last King, pp. 109, 224 n. 4.

${ }^{28}$ Lady Frances Hanbury Williams to Charles Hanbury Williams (hereafter CHW), undated, Lewis Walpole Library, Farmington, CT (hereafter LWL) CHW 83-11393, f. 185.
} 
Lord Essex the works of Archbishop John Tillotson and declared himself 'convincd there is nothing can fortify the mind \& open the way to all happyness more than the faith \& practice of Christianity'. But he added: 'With shame I confess that I did not allways think so. nay I laugh'd at those things. But then I as freely own to you that at that time I had very little knowledge of them. ${ }^{29}$ Of his sexual freedom ample evidence will be supplied. So although I have not yet come across the words 'libertinism', 'libertinage' or 'libertine' in Williams's writings (they were then commoner in French than English), the usage seems justified.

Williams's poems and correspondence offer a rich, perhaps unsurpassed insight into how his set discussed and experienced sex in the 1740s. For whatever reason, the most explicit manuscripts have escaped the pruning to which many other collections have been subjected. Williams's circle (several of whom had been his contemporaries at Eton) included Thomas Winnington, the consummately social politician Henry Fox and his brother Stephen, Edward and Horace Walpole, Sir Charles Wyndham, later second Earl of Egremont, the gambling addict Richard ('Dick') Edgcumbe, later second Baron Edgcumbe, the prolix Henry Harris, who withstood his friends' ridicule of his literary pretensions, and the crudest of the lot, Richard Rigby. Some of them were more clearly attracted to men and boys than were others. ${ }^{30}$ Williams was the bard of the set, a raconteur in White's, and an assassin of the characters of the political foes of Sir Robert Walpole and the brothers Pelham. ${ }^{31}$ He shared friends with Lord Hervey, but they seem to have had little direct contact. ${ }^{32}$ In 1736 Williams joined the Society of Dilettanti - a body which subsequently did sterling work in promoting the study of classical antiquity. In the 1730s, however, it was more of a dining and drinking club for young men who had been on the

${ }^{29} \mathrm{CHW}$ to the Earl of Essex, Berlin, 11 January 1751, new style (hereafter NS), LWL CHW 81-11391, f. 70. Quoted by Ilchester and Langford-Brooke, Sir Charles Hanbury Williams, pp. 234-37.

${ }^{30}$ For three contrasting interpretations, see Brian Fothergill, The Strawberry Hill Set: Horace Walpole and His Circle, London: Faber, 1983; Timothy Mowl, Horace Walpole: The Great Outsider, London: John Murray, 1996; George E. Haggerty, 'Queering Horace Walpole', Studies in English Literature, 1500-1900, 46 (2006), 3, pp. 543-62.

${ }^{31}$ See Urstad, Sir Robert Walpole's Poets, passim.

${ }^{32}$ Smith and Taylor, 'Hephaestion and Alexander', p. 298, n. 71. 
Grand Tour to Italy. The leading light was the notorious rake Sir Francis Dashwood. ${ }^{33}$ However, no evidence has yet come to light that Williams was a member of any 'Hellfire clubs' in the 1730 s or 1740 s. $^{34}$

Before then, Williams had made an unimpeachably uxurious entry into adulthood. His marriage, contracted in 1732, seems to have begun well. Two years later, his wife was still his 'Dearest Life' and he was 'DDD ${ }^{\text {rst }}$ Fannys everlasting lover'. ${ }^{35}$ However, when Charles was in London he fell into a crapulous and incontinent lifestyle with his friends. He pursued liaisons with society ladies, actresses, courtesans, and common prostitutes. He lost his quest for the actress Peg Woffington, whose favours were sought by too many competitors. ${ }^{36}$ In the light of his homoerotic poems, some of which are quoted below, it seems likely, although not certain, that he enjoyed sex with males as well as with females.

In 1742, Williams infected his wife with syphilis. She understandably refused to live with or even to see him, and insisted on bringing up their two daughters herself. Lady Frances could do this, because she had the backing of her own wealthy and high-placed

\footnotetext{
${ }^{33}$ See Jason M. Kelly, 'Riots, Revelries, and Rumor: Libertinism and Masculine Association in Enlightenment London', Journal of British Studies, 45 (2006), 4, pp. 759-95; idem, The Society of Dilettanti, p. 288 n. 86, where he disputes the claims for 'atheism' and 'republicanism' made for the Dilettanti by Shearer West, 'Libertinism and the Ideology of Male Friendship in the Portraits of the Society of Dilettanti', Eighteenth-Century Life, 16 (1992), 76-104. See also Trumbach, Sex and the Gender Revolution, vol. 1, pp.
} 85-90; on Dashwood, cf. Jeremy Black, The British Abroad: The Grand Tour in the Eighteenth Century, Stroud: Sutton, 1992, pp. 67, 73-74, 208.

${ }^{34}$ Dashwood's most (in)famous incarnation of the genre, a pseudo-Franciscan fraternity, met during the 1750s. See Geoffrey Ashe, The Hell-Fire Clubs: A History of Anti-Morality, Stroud: Sutton, 2000.

${ }^{35}$ CHW to Lady Frances Hanbury Williams, Pontypool, 1 December and 3 December 1734, old style (hereafter OS) (12 and 14 December 1734 NS), LWL CHW 83-11393, ff. 1, 21.

${ }^{36} \mathrm{He}$ was much ribbed about this passion, for example by Rigby in this otherwise undated letter of 10 November [OS, 1745?]: 'The Playhouses not being yet open'd, I can send You no account of your dear Woffington, do you never sit in the Mill \& do? as a Mr Floyd that was at Mount Edgcumbe told us a lover of Lady Caroline's [probably Fitzroy, later Viscountess Petersham] did at Euston once: He frigg'd himself at his Own Idea of her, and at first setting out said to himself, I'de give five Pound to fuck Her by God, as He grew more in lust I'de give ten by Christ, in the extasy just before He spent, i'de make it Twenty, immediately after He had spent putting up his Prick, he concluded with; not one farthing, Damn Me. I know your generosity wou'd have increas'd in much larger Sums, but I don't think it unlikely that some afternoon when katty wou'd not come, You may have practised the same method of enjoying a tenor Beauty.' LWL CHW 68-10928, f. 74. Cf. John Brewer, The Pleasures of the Imagination: English Culture in the Eighteenth Century, 2nd edn, Abingdon: Routledge, 2013, pp. 270, 276. 
relations. Charles rarely insisted on his rights as a father, which were - in law considerably greater than hers as an estranged wife and mother. After his five-month cure in Bath for 'the worst case his doctor had ever seen', ${ }^{37}$ Williams continued to console himself with his drinking and whoring companions, but the time would come when paternal feeling would outrank the attractions of a libertine lifestyle.

Mary Margaret Stewart has pointed out with some asperity that most of Williams's poems 'were not meant to be published but rather to be sung among drinking companions or read aloud to friends to gain the reputation of a wit'. ${ }^{38}$ Ribald poems such as Williams's ode to Henry, ninth Earl of Lincoln, also served a political purpose. This celebration of the well-endowed young peer's sexual prowess employed flattery to keep Lincoln in the camp of the Pelhamite Whigs (he was the nephew and successor of Thomas, first Duke of Newcastle). The point was made explicit in the final two stanzas:

Pursue Delight with loosen'd Reins

While Youth is boiling in your Veins

And sparkling in your Face

With whores be lewd, with Whigs be hearty

And both in Fucking and in Party

Confess your Noble Race

To you and steady Pelham then

With Joy I'll dedicate my Pen

For both must be my Theme

Since both divided England share

You have the Love of ev'ry Fair

He ev'ry Man's Esteem. ${ }^{39}$

\footnotetext{
${ }^{37}$ Stewart, 'Williams, Sir Charles Hanbury'. Cf. Ilchester and Langford-Brooke, Sir Charles Hanbury Williams, pp. 55-56.

${ }^{38}$ Stewart, 'Williams, Sir Charles Hanbury'. One of the anonymous reviewers of this article goes further, suggesting that they were probably recited during group masturbation sessions.

39 'An Ode To Henry Earl of Lincoln Wrote in Feb. '1742/3', LWL CHW 69-10930, ff. 80-81. The poem is quoted in full by Black, The British Abroad, pp. 197-98. It was somewhat surprisingly published in Williams's Works, vol. 2, pp. 33-35, with some words replaced by dashes and various other discrepancies.
} 
Williams could also express the sexual norms of his set in a somewhat more refined form - a parody of the style of Henry Harris:

Let Nobler Themes adorn our Feast,

We'd talk by turns, in classick Taste,

Of women, and of Boys;

And envy, who in Gilo's Arms,

Now feeds His Eyes, upon his Charms,

And grasps forbidden Joys. ${ }^{40}$

In other works Williams used earthier language, reminiscent of John Wilmot, second Earl of Rochester; whom he sought to emulate. ${ }^{41}$ Setting pederastic 'Greek and Roman joy' to verse, he hailed young male beauty:
Come to my Breast, my Lovely Boy!
Thou Source of Greek \& Roman Joy!
And let my Arms entwine' ye;
Behold my strong erected Tarse,
Display your plump, \& milk-white arse,
Young, blooming, Ligurine!

\footnotetext{
40 ‘An Ode Humbly inscrib'd to the Rt Honble Thomas Winnington Esqr by Henry Harris Esqr on[e] of the Commissioners of the Wine License 1743', LWL CHW 69-10930, ff. 91-92. Included in Williams's Works, vol. 2, pp. 77-80.

${ }^{41}$ Smith and Taylor, 'Hephaestion and Alexander', at 297. See, inter alia, Graham Greene, Lord Rochester's Monkey, being the Life of John Wilmot, Second Earl of Rochester, New York: Bodley Head, 1974; Jeremy Lamb, So Idle a Rogue: The Life and Death of Lord Rochester, London: Allison \& Busby, 1993; Rachel Weil, 'Sometimes a Scepter is Only a Scepter: Pornography and Politics in Restoration England', in Lynn Hunt (ed.), The Invention of Pornography: Obscenity and the Origins of Modernity, Cambridge, MA: MIT Press, 1993, pp. 125-56; Kirk Combe, A Martyr for Sin: Rochester's Critique of Polity, Sexuality, and Society. Newark, DE: University of Delaware Press, 1998; James William Johnson, A Profane Wit: The Life of John Wilmot, Earl of Rochester, Rochester, NY: University of Rochester Press, 2004.
} 
Howe'er with ev'ry Beauty graced,

Think not those Charms will always last,

To win each Classick Spark;

See Dorset's Duke, \& Grantham too,

The younger pathicks now pursue,

And leave poor Fanny Clark;

And why do's Wynny follow you?

Your blooming Beautys why pursue,

Above each earthly thing?

But that He fly's the lessen'd Grace,

The wrinkle deep, \& sallow Face;

of poor discarded Bing ${ }^{42} 43$

However, it is unclear from the evidence whether or not Williams's love for Winnington ever became physical. The latter told the former they shared his idea of true friendship:

Warmth of Freindship open unreserved Communications, a contempt of Jealousies and suspicions, a Confidence in those you Love and a Defiance of those you hate, without Envy or Fear of either is more suited to my Turn of Mind - and I flatter myself no one agrees more with me in these Sentiments than you. - They are more noble and I think full as Wise. ${ }^{44}$

Winnington, when thanking Sir Charles for the agreeable week he and Harris had spent at Coldbrook in 1745, wrote that it had been 'Nor Vext with Love nor with Ambition

\footnotetext{
${ }^{42}$ Teddy Byng.

43 'Ode to Horatio Townshend, O! crudelis adhue \& Veneris Muneribus potens \&c written at Houghton
} July 1740', LWL CHW 69-10930, f. 19. This poem was understandably omitted from Williams's Works. The first verse is quoted by Smith and Taylor, 'Hephaestion and Alexander', p. 298, and by Dabhoiwala, The Origins of Sex, p. 130n.

${ }^{44}$ Thomas Winnington to CHW, 28 July 1744 OS (8 August 1744 NS), LWL CHW 68-10928, f. 111. 
fixed' ${ }^{45}$ The relationship may well have been emotionally unequal, to judge from the tenor of Winnington's letters.

Sex between women was at least as acceptable to Williams and his companions as sex between men (or between men and boys). In one poem he posed the question of whether Winnington and Etheldreda, Viscountess Townshend, would forsake their companions of their own sex and resume their stormy love affair. These are the final two stanzas:

W What if to Nature I again return,

And for thy beauteous form once more should burn,

Should I quit Bing, would you take back your Winny?

And love again as if the Devil was in ye?

T Tho' Kitty's full of Sentiments refin'd,

Thou rough as Seas, \& fickle as the Wind,

Tho', when I melt in tender Kitty's Lap,

I fear no Children, \& I dread no Clap,

With thee I'd chuse to live, tho' sure to breed,

And take my Lord to bed in case of need. ${ }^{46}$

For Dabhoiwala, this verse implies not the acceptance not only of the equivalence between all-male and all-female liaisons, but also of 'their essential innocuousness' ${ }^{47}$ We should, however, add a caveat: sex between a man and a woman is treated here as 'nature', implying that other combinations are unnatural - however well tolerated and enjoyed. ${ }^{48}$

${ }^{45}$ T. Winnington to CHW, 27 August 1745 OS (7 September 1745 NS), LWL CHW 68-10928, f. 125.

46 'Donec gratus eram tibi \&c - A Dialogue between Mr Winnington \& Lady Townshend', LWL CHW 69-10930, f. 9. It was printed in Williams's Works, vol. 1, pp. 130-31, with numerous discrepancies.

${ }^{47}$ Dabhoiwala, The Origins of Sex, pp. 132-33, where he quotes the poem from 'when I melt' to 'fear no clap', and identifies 'Kitty' as Catherine Edwin.

${ }^{48}$ He took this shot at Frederick II (whom he loathed): 'his unnatural tastes won't allow him to live with her' - the Queen of Prussia. CHW to Henry Fox, Berlin, 30 October 1750 NS, quoted in Ilchester and Langford-Brooke, Sir Charles Hanbury Williams, p. 217. 
Some decades ago, Randolph Trumbach argued that 'Europe was switching from adult male libertines who had sex with boys and with women to a world divided between a majority of men and women who desired only the opposite gender, and a minority of men and women who desired only the same gender'. Furthermore, this shift took place in London between 1660 and $1750 .{ }^{49}$ This thesis is nuanced by Thomas King as a shift from an acceptance of hierarchical 'residual pederasty' to a rejection of gendered 'sodomy'. 50 Others might date this shift to the middle decades of the eighteenth century. ${ }^{51}$ Still others would argue that the change in public discourse had only limited effects on behaviour. Indeed, Dabhoiwala maintains that long eighteenth century brought the further widening of opportunities. Indeed, he claims that the growing practical toleration and even justification of extramarital sex (including that between males and that between females) would in the long term spread far beyond privileged circles of aristocratic libertines. This is a narrative of 'opening up' rather than 'closing down'.52

Be that as it may, for the scholarly arguments show no sign of abating, some of Williams's friends availed themselves of whatever was on offer - occasionally sailing close to the wind of public scandal. In 1744-45 Dick Edgcumbe had a passionate love affair with 'a little whore' - known in the sources only as 'the Kitten' - 'after eight years' acquaintance, and with three or four children'. ${ }^{53}$ The relationship was curtailed - at more

\footnotetext{
${ }^{49}$ Randolph Trumbach, 'The Birth of the Queen: Sodomy and the Emergence of Gender Equality in Modern Culture, 1660-1750', in Martin B. Duberman, Martha Vicinus and George Chauncey jr (eds), Hidden from History: Reclaiming the Gay and Lesbian Past, New York: Meridian, 1990, pp. 129-40, at 130; See also idem, 'Sex, Gender and Sexual Identity in Modern Culture: Male Sodomy and Female Prostitution in Enlightenment England', in John C. Fout (ed.), Forbidden History: The State, Society and the Regulation of Sexuality in Modern Europe, Chicago, IL: University of Chicago Press, 1992, pp. 89-106; idem, Sex and the Gender Revolution, vol. 1, pp. 69-90.

${ }^{50}$ Thomas A. King, The Gendering of Men 1600-1750, vol. 1, The English Phallus, vol. 2, Queer Articulations, Madison, WI: University of Wisconsin Press, 2004-2008, vol. 2, pp. xi-xii, 15-16 and passim.

${ }^{51}$ E.g. Gatrell, City of Laughter, p. 317.

${ }^{52}$ Dabhoiwala, The Origins of Sex, pp. 110-40. Cf. the critical response of Ana de Freitas Boe and Abby Coykendall in their 'Introduction', to de Freitas Boe and Coykendall (eds), Heteronormativity in EighteenthCentury Literature and Culture, Farnham and Burlington, VT: Ashgate, 2014, pp. 1-22, at p. 14.

${ }^{53}$ See Richard Edgcumbe to Horace Walpole, Mamhead, 10 August 1744 OS (21 August 1744 NS), Yale Edition, vol. 30, p. 66. On 'the Kitten', see E. J. Burford, Wits, Wenchers and Wantons - London's Low Life: Covent Garden in the Eighteenth Century, London: Guild Publishing, 1986, p. 108.
} 
or less the same time - by her infidelity and death. ${ }^{54}$ According to Sir Charles Wyndham, Edgcumbe had got over her within three months:

the Kitten is quite forgot, $\&$ he is now most teribly smitten with a Chamber maid of Lady Caroline Duncannons, but having been a week in the house with her without having spoke one word tho he now owns having met her many times alone, I hope this passion will have no bad consequences, $\&$ be only a pretence for a daily bumper at each meal. He did lately call at Olivers but finding no pensionaires he was obliged to bugger an extern \& has told all the particulars of the action in very publick companys to the great astonishment of several grave \& orthodox people, who are much concern'd at the publick avowal of so dangerous a schism. ${ }^{55}$

Edgcumbe's unconsummated passion for Lady Duncannon's chambermaid was recorded in the footnotes of the Yale Edition of Horace Walpole's Correspondence. His risky visit to Oliver's brothel was not. ${ }^{56}$

The inevitable consequence of this lifestyle was that Williams and his friends were continually complaining of syphilis - 'the Clap'. It involved, among other symptoms, excruciating pain in passing water. At the time the only effective cure was mercury, although many other remedies, some involving injections, were tried. Richard Rigby told Sir Charles of how the surgeon Sir Caesar Hawkins 'has giv'n me up to the fucking world again, \& my poor miserable Prick is come out of his Hands quite round with only the loss of a frœnum; I have not yet ventur'd to make use of it but in $\operatorname{armour}^{57}$ I propose the Miller's Wife shall have the Maidenhead of it; for I go to Mistley ${ }^{58}$ on Sunday, for four or

\footnotetext{
${ }^{54}$ Horace Walpole to CHW, London, 25 June 1745 OS (6 July NS), Yale Edition, vol. 30, p. 90.

${ }^{55}$ Sir Charles Wyndham to CHW, London, 9 July 1745 OS (20 July NS), LWL CHW 68-10928, ff. 43-
} 44.

\footnotetext{
${ }^{56}$ Horace Walpole to CHW, London, 25 June 1745 OS (6 July NS), Yale Edition, vol. 30, p. 90 n. 30.

${ }^{57}$ That is, a condom.

${ }^{58}$ Mistley Hall in Essex, his country estate.
} 
five Days. ${ }^{59}$ Some of the set - including Winnington - displayed a dangerous bravado. Rigby informed Williams in 1744:

When I saw your Brother Capel in Town, I was recovering daily \& proposed then the pleasure of being with You at Coldbrook. But alas! however lucky I was with my numberless Bunters all the Winter, Fortune gets Home upon Me now with Cordees \& Heat of Urine. In short at Lord Waldegrave's where I was gone to stay sometime, three days ago I had a most humming Clap come down, which is at present so violent as to wake Me every morning with a loillee. I was so tired with Mercury that I have giv'n up Hawkins for Carey, whose injection at present is reckoned best. I am obliged to a very famous Lady for it \& one who has been much in Fashion these three Weeks or Month I mean Polly Hinley. Numbers will have the like obligation to Her I believe in a few days for she has been liberal of Her Favours. Amongst the rest our great friend her Neighbour ${ }^{60}$ will have good luck if He escapes, having fuck'd Her the day after I lay with Her, she lives in Conduit Street. I have talk'd with Him about it but He magnanimously laughs at the danger \& Defies the Sore. I have had the pleasure of dining at his House 2 or 3 times lately \& See Him three or four times every week. $^{61}$

Some of Williams's poems indicate that while he felt the sordidness and incommodity of his sexual incontinence, he may also have been addicted to unsafe sex for money. This seems to emerge from the following 'song' and its 'parody'. ${ }^{62}$

\footnotetext{
${ }^{59}$ Richard Rigby to CHW, London, 20 June 1744 OS (1 July 1744 NS), LWL CHW 68-10928, f. 59.

${ }^{60}$ Thomas Winnington.

${ }^{61}$ Richard Rigby to CHW, 21 July 1744 OS (1 August 1744 NS), LWL CHW 68-10928, f. 64. Cf.
} Thomas Winnington to CHW, 28 July 1744 OS (8 August 1744 NS), LWL CHW 68-10928, f. 110. 'Rigby is unfortunately Clapt by Molly Henley and has unadvisedly employed Mr Carey the Surgeon to take off his Inflammation.'

${ }^{62}$ This, and another, similar 'Song' are on LWL CHW 69-10930, f. 71, this, and another 'Parody' on f. 72. The former were printed in Williams's Works, vol. 1, pp. 254, 255, the latter - not. 
At St Osyth's near the Mill,

There dwells a lovely Lass;

O! had I her good Will,

How sweetly Life would pass!

No bold intruding Care,

Our Bliss should e'er annoy;

Her looks can gild despair,

And heighten ev'ry Joy;

Like Nature's Rural Scene,

Her artless Beauties charm;

Like them with Joy serene

Our wisting Hearts they warm,

Her Wit with Sweetness crown'd,

Steals ev'ry Sense away,

The listing Swains around,

Forget the short'ning Day.

Health, Freedom, Wealth and Ease,

Without her tasteless are,

She gives them Pow'r to please,

And makes them worth our care.

Is then Ye Pow'rs a Bliss

Reserved for my Share?

Indulgent, hear my Wish,

And grant in all in Her.
At St Giles's near the Pound,

There lives a bunting Lass;

O! had I her but sound,

How wholesome Life would pass!

No bold intruding Clap,

Would make my Urine sore;

I'd wanton in Her Lap,

and on Her Bubbies snore;

With Patch and Paint o'erspread

Her artfull Beautys charm

Like those too in Her Bed

Her falser Raptures Warm

Her C-t with Chancres crown'd

Makes Ev'ry P-k decay

The Swains all clapp'd around,

Take Physick ev'ry day.

Broil'd Fowl, 'Rack Punch, \& Wine,

Without Her lose their Taste,

She makes the Liquor fine,

And garnishes the Feast.

Ye Surgeons have you art,

My Bunter to restore?

O! cure the infected Part!

I'll f-k no other Whore.

So he would go to Coldbrook for the summer, to live a quiet and self-disciplined life, giving his cure time to take effect, before returning to his former wild ways in 
London. ${ }^{63}$ Wyndham told Williams in June 1745 that he was sorry, but not surprised to learn that he had been ill on his journey to Monmouthshire, 'after the six months you spent in town in which tho your mind was in constant exercise, your body knew no motion but the gentle motion of a crane neek'd charriot to convey you from the joys of the bed to those of the table \& so back again'. ${ }^{64}$ Williams had earlier shared his versed thoughts with a clerical friend:

Easy where'er I am for I can stay

Six months in Wales yet know no tedious Day

There regularly study eat $\&$ sleep

And sober meals and early Hours I keep

But when th'invested year wears Winters Frown

My Coach is order'd and I drive to Town

There dash into a Stream of new Delight

Enjoy my Friends by day my Nymph by Night

By this time, however, at least two of Williams's friends were applying the brakes to their lifestyle. Later in the same poem we read a melancholic toast:

Such are the Nights that I have seen of Yore,

Such are the Nights that I shall see no more,

When Winnington and Fox with flow of Soul,

With Sense and Wit drove round the chearfull Bowl;

Our Hearts were open'd, and our Concourse free,

But now they both are lost, quite lost to me;

${ }^{63}$ One prolonged retreat prompted an attempt from Richard Rigby to tempt Williams back to London: 'Don't you begin to be almost tired of the country: I have a notion you wou'd give a good deal for one night at Ranelagh \& White's: not to mention a fuck which I suppose You begin to have some occasion for by this time: to comfort you I will tell you one thing if You will rely upon it, which is, that Doncraile has declar'd to Me upon his Honour, he said, that he never did fuck the Woffington in his Life, I love to send my friends all the agreeable news I hear \& therefore cou'd not omit this.' Rigby to CHW, London, 27 June 1745 OS (8 July 1745 NS), LWL CHW 68-10928, f. 70.

${ }^{64}$ Sir Charles Wyndham to CHW, Petworth, 16 June 1745 OS (27 June 1745 NS), LWL CHW 73-11385, f. 251 . 
One to a Mistress gives up all his Life,

And One from me flies wisely to his Wife,

There proves the highest Joys that Man can prove,

The Joys of Truth, and of Alternate Love;

Each happy in his different Path - Go on

Pleas'd and Content - I pensive and alone

Rejoyce at both your Fates - but Mourn my Own. ${ }^{65}$

Indeed, it was Williams who set up Henry Fox's clandestine marriage to Lady Caroline Lennox in his own house in Conduit Street, Mayfair in 1744. He appreciated the value of their loving and well-matched union. ${ }^{66}$ The Foxes later rented the same property before setting up at Holland House.

After Winnington's death in 1746, references to Sir Charles's sexual activity become significantly rarer, and cease altogether after 1750. When in August of that year Williams rapturously described Kazimierz Poniatowski (Stanisław's elder brother) to Fox, it is not clear from the passage that any physical relations had taken place.

There is a Person here who is Great Chamberlain of Poland who is the finest person of a Man that I ever lookd at \& his face is the exact resemblance of that enamill that Link did of Lady Townshend half naked. the likeness is so strong that it struck me, \& it woud be worth her Ladyships while to come to Warsaw to taste his Person. If she had not behavd so ill to me I coud write her the most touching letter upon this Young Nobleman that ever she read. ${ }^{67}$

65 'To the Reverend Samuel Hill, Canon of Wells, \&c. \&c., Written in August, 1744', LWL CHW, 6910930, f. 13, and LWL 2050 22B. Published in Williams's Works, vol. 2, pp. 57-62.

${ }^{66}$ Stella Tillyard, Aristocrats: Caroline, Emily, Louisa and Sarah Lennox 1740-1832, London: Vintage, 1995, pp. 28-31. Winnington compared his own situation with Lady Townshend to that of the Foxes, writing to CHW on 28 July 1744 OS (8 August 1744 NS): 'Harry Fox I see as often as he comes to Town to attend the Treasury which is once a week and he is then in hast to go to his Dear Lady Caroline - His Wife is his Mistress and my Mistress is my Wife - I dont know which is the most happy but I know who is the most at Ease', LWL CHW 68-10928, f. 110.

${ }^{67}$ CHW to Henry Fox, Warsaw, 22 August 1750 NS, BL Add. MS 51392, ff. 123-24. 
Jean Fabre surmised that Williams had an affair with Kazimierz, which gave rise to later, entirely misleading rumours about the nature of his relationship with Stanisław. ${ }^{68}$ This cannot be excluded. On the other hand, by this stage Sir Charles may no longer have been able to perform satisfactorily. For three weeks earlier he had admitted to Fox: 'My flame at Hanover was like the Glow Worm's an Ineffectual one', despite the charms of a widow. ${ }^{69}$

Williams's perspective on libertinism had now become that of a father (albeit largely a corresponding one) and father-figure. By the late 1740s, he had come to enjoy dispensing sound, worldly advice to young gentlemen. One of the first to benefit was young Philip Stanhope, the fourth Earl of Chesterfield's illegitimate son. Chesterfield, the Gallomaniac scourge of social awkwardness, slovenly comportment, and disgusting personal habits, asked Williams to correct his son's faults during the latter's stay in Dresden during the course of his Grand Tour. Young Stanhope later thanked Sir Charles for the good account he had given of him to Chesterfield, adding however: 'as to my awkwardness and Inattention I promise you I will try to get rid of them as soon as I can.' Given Chesterfield's concern that his son should gain the right kind of sexual experience with a lady of high rank (which became notorious when Chesterfield's Letters to His Son were posthumously published in 1774), it is pertinent to note that Williams seems to have concurred in the advice. For Stanhope confided in him: 'As to my amours in Italy I believe the fewer here the better, I am however just fallen desperately in love with no less a lady than a Princess. ${ }^{70}$

Williams was less exquisitely refined than Chesterfield, and so less vulnerable to the charge of encouraging duplicitous conduct in the young. ${ }^{71}$ But their views were similar regarding the externals of agreeable behaviour. This is well exemplified by the work Williams put into polishing Harry Digby, grandson of Baron Digby and nephew to Henry Fox. At the end of 1749 Sir Charles still had a reputation to live down. He 'receivd a letter from Harry Digby by which I find that My Lord consents to his going with me \& that He hopes I wont corrupt his Grandson as I am not a Virtuous Man. - I do assure you that I will

\footnotetext{
${ }^{68}$ Fabre, Stanislas-Auguste Poniatowski, pp. 150, 172.

${ }^{69}$ CHW to Henry Fox, Berlin, 1 August 1750 NS, BL Add. MS 51392, ff. 119-20.

${ }^{70}$ Philip Stanhope to CHW, Rome, 27 December 1749 NS, LWL CHW 68-10928, ff. 143-44.

${ }^{71}$ On the reactions to the publication of Chesterfield's Letters to His Son, not all of them critical, see Roger Coxon, Chesterfield and His Critics, London: Routledge, 1925; Curtin, 'A Question of Manners', pp. 396, 403-08; Carter, Men and the Emergence of Polite Society, pp. 78-79.
} 
teach him nothing but what is strictly good. \& take as much care of him as if he was my own Grandson. ${ }^{72}$ Williams relished the challenge, but soon made an unwelcome discovery: 'He has the remains of an ill curd or uncur'd clap about him, for which when He comes to Berlin I shall make him live very low, \& carefully, till an able Physician that lives there tells me He is perfectly well. ${ }^{73}$ Ever practical, Fox recommended 'an injection [...] to cure his present disorder, and condoms, which if he pleases I am sure may prevent future ones' ${ }^{74}$ At this point Williams also had Harry's elder brother Edward (Neddy) on his hands, with a similar affliction. ${ }^{75}$

For Harry Digby, who was not expected to inherit much (in fact he did succeed to the family's Irish peerage and ultimately rose to a British earldom), the social graces needed for a career in diplomacy or politics were essential. Sir Charles praised his good nature and pleasing frame and visage to Fox, but found much to correct, including 'his pickin his teeth, his nose and his ear with the same finger.' He asked Fox's help, in the form of letters to Digby 'on the chapter of inattention in company \& personal awkwardness. ${ }^{76}$ Williams persevered, and Digby improved to the point where, like young Stanhope, he was pronounced fit for a minor diplomatic legation. ${ }^{77}$ Part of the therapy had been the exemplary company of Stanisław Poniatowski.

Stanisław had been a morose youth at first, but he blossomed under Williams's tutelage and soon needed different advice. When in one of his letters from Vienna he expressed regret that Harry Digby had not met Count Ludwig Friedrich Julius Zinzendorf ${ }^{78}$ (whom he later recalled as having 'le propos, les manières et toute la façon di vivre d'un vieux libertin français' $)^{79}$ Sir Charles was alarmed. He warned Poniatowski against letting

\footnotetext{
${ }^{72}$ CHW to Henry Fox, Coldbrook, 24 December 1749 OS (4 Jan 1749 NS), BL Add. MS 51392, f. 72.

${ }^{73}$ CHW to Henry Fox, Hanover, 6 June 1750 NS, BL Add. MS 51392, ff. 96-98.

${ }^{74}$ Henry Fox to CHW, late 1750, quoted after Black, The British Abroad, p. 192.

${ }^{75}$ CHW to Henry Fox, Berlin, 1 August 1750 NS, BL Add. MS 51392, ff. 119-20.

${ }^{76}$ CHW to Henry Fox, 3 October 1750 NS, BL Add. MS 51392, f. 149, quoted at greater length in Butterwick, Poland's Last King, p. 99.

${ }^{77}$ CHW to Henry Fox, 1 January 1752 NS and 8 March 1752 NS, BL Add. MS 51393, ff. 71, 83.

${ }^{78}$ Stanisław Poniatowski to CHW, Vienna, 29 January 1752 NS, cited in Butterwick, Poland's Last King, p. 89.

${ }^{79}$ Stanislas Auguste, Mémoires, p. 53.
} 
his admiration become imitation. Zinzendorf, he explained, had 'esprit' (a word whose meaning combines 'spirit' and 'wit') but in Williams's opinion that was his only merit. Having made enemies of his friends by 'bons mots', Zinzendorf was now condemned to reflect on his ill-spent youth. Stanisław did not lack 'esprit'. He had better spend his time acquiring 'du bon sens, du Jugement et de l'Expérience' in better company. ${ }^{80}$ Sir Charles feared that premature social acclaim might make Stanisław conceited and foolish. ${ }^{81}$

Poniatowski's manners, looks, carriage, and conversation were much admired, ${ }^{82}$ and by the beginning of 1755 Williams felt that there was little left but to 'correct those few strokes of what the French call Humeur that you still have about you' (after Poniatowski's stay in England in 1754 Williams usually wrote to him in English). ${ }^{83}$ In $\mathrm{St}$ Petersburg Sir Charles was able to take Stanisław's education several stages further. ${ }^{84}$

With a benign eye Sir Charles facilitated Stanisław's first serious love affair - with the Grand Duchess Catherine. The three shared a taste for racy literature; Poniatowski read Voltaire's Pucelle d'Orléans to Catherine. The book's delivery had been greeted by Williams with 'un cri de joye' ${ }^{85}$ By the time that Poniatowski had left St Petersburg for the first time, in the summer of 1756, Williams had come to feel for him as his adopted son - a sentiment reciprocated by the younger man towards his 'second Pere' or 'Pere adoptif'. Working with Catherine to procure Stanisław's return to Russia as a Saxon envoy, he told her that he would receive him as his son, although they now found themselves on opposite sides in the Seven Years' War and could not talk politics. ${ }^{86}$

Williams had no son of his own, and spent most of his adult life far from his two daughters: Frances, who married the Earl of Essex in 1754, and Charlotte, who married

${ }^{80} \mathrm{CHW}$ to Stanisław Poniatowski, 18 February 1752 NS, quoted after Butterwick, Poland's Last King, p. 89-90.

${ }^{81}$ CHW to Stanisław Poniatowski, 21 January 1752 NS, quoted in Butterwick, Poland's Last King, p. 90.

${ }^{82}$ Among others by Horace Walpole ('He is very handsome'), in a letter of 14 May 1754 NS to John Chute, which also recorded Poniatowski's extraordinary reception by Katherine, Dowager Duchess of Gordon. Yale Edition, vol. 35, pp. 81-82; Butterwick, Poland's Last King, pp. 109-10.

${ }^{83}$ CHW to Stanisław Poniatowski, 8 January 1755 NS, quoted after Butterwick, Poland's Last King, p. 92.

\footnotetext{
${ }^{84}$ Butterwick, Poland's Last King, pp. 97-98.

${ }^{85}$ Stanislas Auguste, Mémoires, p. 132.

${ }^{86}$ Butterwick, Poland's Last King, pp. 93-94.
} 
long after her father's death. Long before his recall from Russia he had had enough of the diplomatic life and longed to divide his time between three more congenial roles: squire of Coldbrook, friend of the Foxes at Holland House, and grandfather to the children of the Earl and Countess of Essex at Cassiobury in Hertfordshire. Sir Charles's numerous letters to his daughters set out his expectations of daughterly and wifely conduct. There is no hint of equality in these roles, but he clearly saw himself as a loving, affectionate modern parent, friend and educator, rather than a stern, traditional paterfamilias. He was shocked and angered, for example, to learn that his wife had whipped the fourteen-year old Charlotte for reading Tom Jones. ${ }^{87}$ Williams the father is without doubt worthy of a separate study in eighteenth-century paternity. ${ }^{88}$ In the present context we might note that on one occasion he wrote to his daughter, Charlotte: 'Indeed my Charlot you are grown a very great Rake; You dance at Balls till you cannot stand, and stay at Ridottos till three of the Clock in the morning, ${ }^{89}$ This was hardly a reproach to a female libertine; ${ }^{90}$ Sir Charles was pleased that his younger daughter, who suffered from a disfigured arm, and was regularly upbraided by her sister for her slatternly dress and deportment, was enjoying company. His hopes must have risen for her marriage.

$* * *$

What conclusions can be drawn from this material? With such a window into Sir Charles's heart and mind, we can surmise that energies he had expended sexually in the early 1740s were later sublimated into paternity and pedagogy. The advice to his daughters both contrasts and compares with that he gave Poniatowski, Essex, Stanhope, and Digby. They

\footnotetext{
${ }^{87}$ Ilchester and Langford-Brooke, Sir Charles Hanbury Williams, p. 232.

${ }^{88}$ See, inter alia, Lawrence Stone, The Family, Sex and Marriage in England 1500-1800, London: Harper Collins, 1977; Randolph Trumbach, The Rise of the Egalitarian Family: Aristocratic Kinship and Domestic Relations in Eighteenth-Century England, New York: Academic Press, 1978, ch. 6; Anthony Fletcher, Gender, Sex and Subordination in England, 1500-1800, New Haven, CT: Yale University Press, 1995, part 3. As has been argued since, contrasts between 'traditional' and 'affectionate' parenting can be exaggerated. See Harvey, The Little Republic, pp. 3-8, and references therein.

${ }^{89}$ CHW to Charlotte Hanbury Williams, Dresden, 26 March 1755 NS, LWL CHW 76-11387, f. 66.

${ }^{90}$ Cf. Kathleen Wilson, 'The Female Rake: Gender, Libertinism and Enlightenment', in Cryle and O’Connell (eds), Libertine Enlightenment, pp. 95-111.
} 
compare because his advice to both male and female protégés encapsulate much of the culture of eighteenth-century politeness. This politeness, as Jeremy Black, prompted by the language employed in Williams's circle, has noted, was 'deliberately inculcated in order to cope with a very different culture' - rude, ribald, riotous and rebellious, redolent of Rochester and the Restoration. ${ }^{91}$ The older and wiser Williams was one of those best placed to know the purposes of such politeness - and the permissible limits of impolite conduct. Moreover, as Michael Curtin concluded, until the mid-eighteenth century, courtesy literature was still 'addressed to an audience which was presumed to be youthful, high-spirited, and aggressive, but which required an admixture of restraint and selfdiscipline for the pursuit of worldly distinction. ${ }^{92}$ What may require emphasis, however, is the extent to which carriage and conduct mattered, to Williams as it did to Chesterfield.

The advice dispensed by Sir Charles to young men also contrasts with that given to young women, because although he still enjoyed the society of highly sexualized women, the middle-aged Williams did not depart from the conventional double standards of the age when it came to his own daughters' chasteness. We might also reflect that young gentlemen's numerous and varied opportunities for libertine conduct diverted their attention away from the young ladies they might otherwise have seduced, and so helped to keep disconcerting problems of female sexuality at a safe distance from their fathers.

It may seem a clichéd observation, but Williams belonged to a transitional generation in the histories of the family and of sexuality. ${ }^{93}$ It is as misleading as it is tempting to interpret the transformation in Williams's own preoccupations in the late 1740s as part of a more general shift from the embers of Restoration libertinism towards the tender, indeed lachrymose parenting conventions of the age of Sensibility. This apparently sudden change in Sir Charles may in part result from the chance preservation of the sources: a rich seam of 'libertine' letters from the mid-1740s has survived, rather than having been burnt. Williams's daughters reached an age at which he might - if he chose begin to take a closer interest in their education and their settlement after he had gone overseas and begun to correspond frequently with them. We should not imagine that before

\footnotetext{
${ }^{91}$ Black, The British Abroad, p. 194. Gatrell, City of Laughter, p. 617 n. 1, also makes the point that 'politeness itself reacted' against 'autonomous' 'manly codes'.

${ }^{92}$ Curtin, ‘A Question of Manners', p. 418.

93 'The generation between 1720 and 1750 can sometimes seem the hardest of all to bring into focus', Trumbach, Egalitarian Family, p. 291.
} 
the late 1740s Williams had no concern for his daughters, or that he was incapable of conducting himself politely when the circumstances demanded it. He might be compared in this respect to John Wilkes, who was both 'neglectful husband' to his wife and 'sentimental parent' to his daughter Polly, and who defies sharply drawn contrasts between libertinism and domesticity. ${ }^{94}$ Nor should we assume that Sir Charles renounced all carnal pleasures following his posting to Dresden. The spirit, however, was by then probably more willing than the flesh.

The sources concerning Williams's set in the 1740s tend to fit Roy Porter's classic claim that 'amongst the affluent and leisured' of Georgian England, 'the libido was liberated and erotic gratification was dissociated from sin and shame' ${ }^{95}$ This celebratory interpretation has recently been reinforced by Dabhoiwala's 'first sexual revolution'. The evident persistence of a 'rakish, bisexual, libertine' culture into the mid-eighteenth century (shortly before the rise of the 'blackguards' associated with 'heteronormative' Wilkite libertinism $)^{96}$ might seem to call further into question the early eighteenth-century shift postulated by Trumbach, away from the old libertinage involving the pursuit 'of boys and women' in consequence of the stigmatization of homosexual behaviour as 'effeminate'. 97 We should however distinguish between 'coexisting models' and 'dominant discourses', or to put it less theoretically, between things that could be expressed privately and things that could be said publicly. ${ }^{98}$ Very little (if any) of the material presented above was intended

\footnotetext{
${ }^{94}$ See John Sainsbury, John Wilkes: The Lives of a Libertine, Farnham and Burlington, VT: Ashgate, 2006, pp. 9-40.

${ }^{95}$ Roy Porter, English Society in the Eighteenth Century, London: Allen Lane, 1982, pp. 282ff.

${ }^{96}$ See John Sainsbury, 'Wilkes and Libertinism', Studies in Eighteenth-Century Culture, 26 (1998), pp. 151-74; idem, John Wilkes, pp. 96-100; this argument is pushed still further by Declan William Kavanagh, 'John Wilkes's “Closet”: Hetero Privacy and the Annotation of Desire in an Essay on Woman', in Ana de Freitas Boe and Abby Coykendall (eds), Heteronormativity in Eighteenth-Century Literature and Culture, Farnham and Burlington, VT: Ashgate, 2014, pp. 77-94.

${ }^{97}$ The point has been made for Hervey's circle in the 1730s, partly by referring to Williams. Smith and Taylor, 'Hephaestion and Alexander', pp. 297, 311.

${ }^{98}$ Carter, Men and the Emergence of Polite Society, pp. 136-37, 209. See also idem, 'An "Effeminate” or "Efficient” Nation? Masculinity in Eighteenth-Century Social Documentary', Textual Practice, 11, 1997, pp. 429-43; Sally O’Driscoll, 'The Molly and the Fop: Untangling Effeminacy in the Eighteenth Century', in Chris Mounsey (ed.), Developments in the History of Sexualities: In Search of the Normal, 1600-1800, Plymouth: Bucknell University Press, 2013, pp. 145-72; On the avoidance of explicit terms in print, see
} 
for publication. These exceptionally rich sources encourage us, then, to explore questions of mid-eighteenth-century friendship, sexuality, paternity and politeness 'below' the level of public discourse. As the scholarly debate moves on, new interpretations can be expected. But before finishing, let us return - in the imaginations of Sir Charles and our own - to Monmouthshire.

After his last departure from Britain in 1754, Williams's thoughts increasingly turned homewards. He told Revd James Birt, who acted for him there: 'Coldbrook is my Coffin and I hope to pass my latter days there. ${ }^{99}$ He planned improvements at the estate, including a kitchen garden, received the local news, and anticipated the tranquillity and comfort in which he could recall his adventures abroad. Birt was to imagine him 'at the Head of the table with a Daughter on each side of me and yourself saying Grace at the Bottom', [...] enjoying all those heartfelt Sensations that reciprocal Tenderness and Friendship can produce. ${ }^{100}$ To Charlotte he reflected:

Ambition is dead in me, and I have hardly any taste left for all that I once called Pleasure. Nobody can believe but those that have experienced it how ones Ideas change with the Stages of Life, nor how much the reasonable Passions by the assistance of time get the better of the strong ones, tho' in the greatest Wildness of my Youth, I always had a Love for Books, which now grows more and more upon me $[\ldots]^{101}$

Sir Charles Hanbury Williams had been, first and foremost, a literary rake. Perhaps the very libertinism which once purged him from the history of English literature may yet bring him a place in the canon.

Karen Harvey, “"The Majesty of the Masculine Form”: Multiplicity and Male Bodies in Eighteenth-Century Erotica', in Hitchcock and Cohen (eds), English Masculinities, pp. 193-214. Cf. Smith and Taylor, 'Hephaestion and Alexander', p. 304ff., for the 'reluctance to allow public scrutiny of aristocratic libertinism', and the consequent force of William Pulteney's attack on Hervey as an effeminate sodomite.

${ }^{99}$ CHW to James Birt, Dresden 15 March 1755 NS, LWL CHW 76-11387, f. 51.

${ }^{100}$ CHW to James Birt, St Petersburg, 12 October 1756 OS/23 October 1756 NS), LWL CHW 76-11387, ff. $165-71$.

${ }^{101}$ CHW to Charlotte Hanbury Williams, Warsaw, 2 October 1754 NS, LWL CHW 81-11391, ff. 285-86. 